\title{
Application of Lean to Hotel's Operations Raising housekeeping productivity
}

\author{
Mohd Haris Manaf \\ School of Hospitality, Republic Polytechnic \\ Singapore 738964 \\ Singapore \\ Haris_manaf@rp.edu.sg
}

\begin{abstract}
The hospitality sector in Singapore is facing a very tight labour market due to a combination of factors, namely, increasing youth aspiration, better educated workforce and the national labour policies on foreign workers. The hotel sector is particularly affected, especially the housekeeping department. Hotels in Singapore are now exploring ways to raise their housekeeping productivity, so as to be able to meet operational requirements albeit the smaller number of staff. Therefore, the aim of this applied research study was to explore the applicability of Lean, which has been successful in manufacturing, to hotel's operations, particularly the housekeeping operations. Lean Management was therefore used to improve the productivity of the hotel housekeeping operations. A DMAIC (Define, Measure, Analyse, Improve and Control) approach, which is commonly used in Lean project, was adopted for this project. The data was analysed using Lean analysis tools and revealed the following:
\end{abstract}

1. Non-value added activities, that is, those that are not directly related to cleaning (processing) the room, account for as much as $44 \%$ or 211.2 minutes of the room attendant's 8-hour work shift.

2. The cause and effect and waste analysis of the non-value added activities indicated that transportation and motion type wastes account for $18 \%$ of the non-value added activities while process design and inventory and supply management account for $26 \%$.

3. Room attendants' job scope design that requires room attendants to be responsible for guest laundry causes them to lose up to 54 minutes each time there is a guest laundry request.

Improvement was focused on waste elimination. A houseman role was introduced to relieve the room attendants of the non-value added activities they currently perform. In addition, the housekeeping department implemented basic $5 S$ to organize its back of the house, specifically the floor pantries. Regular department briefings were also moved to non-critical operation period and kept succinct.

The post implementation measurement indicated that the streamlined processes freed 85 minutes of the room attendant time per shift. This enabled room attendant's daily room output to be raised from 15 rooms per shift to 18 rooms per shift which represent a $20 \%$ increase in output without incurring any additional hours.
In conclusion, this study provided evidence that Lean can be applied to hotel operations and can have a significant impact on work outcome. By redesigning work processes and systems to be leaner, a 20\% increase in daily work outputs was possible. To drive output and efficiency event further, hotels should also explore automating some of their labor intensive process through the use of Information and Communication technology, smart devices, Radio Frequency Identification devices (RFID) and robotics.

Key Words--Lean, Hotel Operations, Productivity Improvement, Housekeeping, automation

\section{INTRODUCTION}

Singapore's hospitality sector is facing a very tight labour market due to a combination of factors, namely, the national labour policies on foreign workers, better educated workforce, changing youth aspirations and life priorities and expectations and an aging population.

In 2010, the Economic Strategies Committee set up by the Singapore government to develop Singapore's future economic strategies, recommended that Singapore shift to a productivity-driven growth where companies must compete through innovation, investment in people and creating high value jobs. A key trust in this strategy is to better manage the country's dependence on foreign worker (Ministry of Manpower, 2012). In 2010, the population of foreigners and permanent residents in Singapore stands at 36 per cent, compared to 10 per cent in 1980. A sharp increase was seen during the period 2004 to 2009 where non-resident employment in Singapore labour force ${ }^{1}$ rose by $7 \%$ that is from

\footnotetext{
1 Singapore's labour force is broadly classified into residents (including citizens and permanent residents) and non-residents. Non-resident workforce includes Employment Pass Holders (EPH), Special Pass Holders (SPH) and Work Permit holders (WPH). EPHs are considered most skilled, with almost no restriction in numbers except that they should meet a minimum salary requirement. On the other end of the spectrum are the WPHs, which are considered least skilled. They are most employed in manufacturing, construction and domestic help sectors. Employers hiring WPHs will have to pay a levy, and WPH employment also comes with various restrictions. SPHs are in between EPHs and SPHs, and are mostly employed as service workers.
} 
$28 \%$ at the end of 2004 to $35 \%$ by the end of 2009 (Soon \& Thia, 2012). Although the government acknowledge the role and importance of foreign workers in certain sectors such as tourism-related service sectors, the number of foreign workers must be better manged or else real physical and social limits will quickly be reached. In recent years, increase in anti-foreigner sentiments, has become evident in both Singapore's online and offline media (Ho, 2012). Furthermore, the Singapore government is of the opinion that if access to foreign labour is too easy, companies may not be incentivised to invest in productivity improvements. As such measures to moderate the number of foreign workers were introduced in the forms of levies and quotas (Economy Strategies Committee, 2011). With the gradual introduction of these levies and quotas over the last few years, businesses operating in labour intensive sectors such as hotels, food services and retails are finding it increasingly difficult and costly to staff their operations.

The quotas also mean that businesses wanting to hire foreign workers will need to first hire Singaporeans. However, with improvements in the level of education amongst Singapore residents (Department of Statistics Singapore, 2016), Singaporeans are also shunning manual and laborious jobs (Soon \& Thia, 2012). According to the latest General Household Survey by Singapore's Department of Statistics, the proportion of resident (non-students) with postsecondary qualification increased significantly across all age groups. In 2014, 51.2\% of the resident population aged 25 years and above had at least post-secondary education. This represents a $17.3 \%$ increase over 2004 percentage of $22.9 \%$ (Department of Statistics, 2015).

With higher education come higher aspirations. According to a global survey by the Chartered Institute of Management Accountants (CIMA) (Chartered Institute of Management Accountants, 2013), Generation Y aspires to climb the corporate ladder but they wanted to do so on their own terms. Findings from the study showed that $34 \%$ of the respondents hoped to be in a senior management role by the age of 35 . At the same time, maintaining a healthy work life balance is an important part of career progress and work satisfaction.

As with their global counterparts, local new entrants into the workforce are also expecting better jobs and an accelerated career progression. It is not uncommon to hear young employees expecting supervisory or managerial jobs within their first 12 months on the job. Similarly, Singaporean youths are also expecting better work- life balance (Singapore Polytechnic, 2014). The new generation of more educated workers does not mind the hard work but they expect to be able to enjoy the fruit of their labour at the same time. Singapore present workforce is also aging. The median age of Singapore citizens in 2011 is 39 . This is expected to rise to 47 if the current trends in birth rates and immigration continue. The number of elderly citizens aged 65 and above will reach 900,000 by 2030 , triple today's number. The number of working residents will also begin to shrink by 2020 and by 2030 it is projected that there will be only 2.1 working-age resident to support each resident aged 65 and above compared to 4.8 in 2015 (National Population and Talent Division PMO Singapore, 2012).

These factors are the major causes of Singapore's very tight labour market in relation. The following excerpt taken from Singapore's Ministry of Manpower addendum to the President's speech 2016 sums up Singapore's industry and manpower challenges and underlines the importance of establishing the framework for productivity improvement driven by technology and innovation;

"Singapore is at a turning point. We have a more educated generation with diverse aspirations and needs. We have an ageing population with baby boomers retiring in increasing numbers over the next decade. We face a volatile global economy, keener competition, and faster technological change. To sustain a nation of opportunity, we need to transit from a manpower-led to a manpowerlean economy. Even as we reap the benefits of growth, we must be inclusive in our approach so as to build a society that cares."

In transiting from a "manpower-led" economy to a "manpower-lean" economy, companies are expected to embrace productivity and innovation, and reduce reliance on low-skilled foreign manpower. By doing this the Singapore government hopes that more high-quality jobs can be created for Singaporeans.

\section{LEAN}

Organisations have to operate in highly competitive market place, uncertain economic climate and demanding customers who now have instant access to information and market places. Running highly reliable fast pace operations with superior ability to adapt to changing market conditions while continuously improving and maintain the lowest cost of doing business, are critical factors for organisations to survive and thrive in this competitive economy (Ward \& Duray, 2000) (Voss, 2005). Over the years, there have been a growing number of continuous 
improvement models based on the notion of improved processes aimed at reducing waste, simplifying production line, and improving quality. Some of these includes, total quality management (TQM), lean manufacturing, Six Sigma and Lean Six Sigma (LSS) (Costa, Lima, \& Garbuio, 2014).

Lean approach was a term used to describe the new management techniques of the Japanese automotive industry which utilizes less resources compared to mass production (Wormack, Jones, \& Roos, 1990). Up to today, discourse on lean approach continues, moving away from best practice production techniques in the automotive sector to include other techniques/approaches and sectors within manufacturing (Abdi, Shavarini, \& Hoseini, 2006). According to Wood (2004), lean approach is not about zero inventories or a collection of tools applied mechanically to problems nor is it a Japanese philosophy to be applied indiscriminately. According to him, it is a 'way of giving people at all levels of an organization the skills and a shared means of thinking to systematically drive out waste by designing better ways of working, improving connections and easing flows within supply chains'. By removing waste organizations can simultaneously achieve cost reduction, optimize resources and deliver better customer value (Wood, 2004). Womack and Jones (1996) define waste in the context of "Lean Thinking" as "any human activity, which absorbs resources but creates no value". Womack and Jones (1996) also put forward as a framework for implementation of Lean in organizations, 5 principles of "Lean Thinking" which are:

1. Specify what customers Value: Value refers to exactly what customer wants which requires a precise understanding of the specific needs of the customer.

2. Understand the Value Stream: The value stream comprises activities that produce the product or service that the customer values

3. Improve the Flow: In a lean organization work flows steadily and unhindered from one value adding or supporting activity to the next. Every effort is made to eliminate obstacles and bottlenecks.

4. Pull: This refers to how customer demand determines the flow of value producing system should react to customer demand unlike in nonlean organizations work is pushed through the system at the convenience of the operators.

5. Perfection: A lean system is about continuous improvement therefore over time it becomes leaner and faster and more and more waste gets eliminated. A perfect process is one that delivers just the right amount of value to the customer.
Toyota executive, Taiichi Ohno, identified seven types of waste namely; waiting, overproduction, defects, unnecessary motion, unnecessary inventory, inappropriate processing, and transporting. Womack and Jones (1996) added an eight waste, that is, design of goods and services which do not meet customer's needs.

\section{LEAN IN SERVICE}

According to Alsmadi et al (2012), in the past two decades, Lean has been primarily used to improve manufacturing processes. However, there has been a realisation amongst service firms that Lean can potentially benefit service operations as well. Market uncertainties, increasing competition and increasingly demanding consumers are forcing service firms to turn to Lean to help improve operations and competitiveness (Alsmadi, Almani, \& Jerisat, 2012). In a highly competitive market place service is becoming increasingly generic. Customers see total service quality as the principal differentiator, Therefore the key to survival is to be able deliver high quality service efficiently and with the agility to respond to changing market needs and emerging market niches (Yusuf, Gunasekaran, \& Dan, 2007). Therefore applying proven manufacturing improvement techniques, such as Lean practices, to service operations may help service operations gain competitive advantage. Womack and Jones (2003) have set out six additional principles of what they call lean consumption that correspond closely with those of lean production:

1. Solve the customer's problem completely by ensuring that all the goods and services work, and work together.

2. Don't waste the customer's time.

3. Provide exactly what the customer wants.

4. Provide what's wanted exactly where it's wanted.

5. Provide what's wanted where it's wanted exactly when it's wanted.

6. Continually aggregate solutions to reduce the customer's time and hassle.

These principles recraft traditional lean thinking principles and make them more applicable to a service context. Lean thinking or approach however is still new to the service industry in particular the hotel industry.

This applied research study therefore intended to study the application of Lean thinking in a hotel operation setting; namely Housekeeping and provide some empirical evidence on its impact on the said operation. 


\section{SINGAPORE HOTEL SECTOR}

\section{A. Snapshot}

Fig. 1 provides an overview of Singapore's hotel industry. In the last 5 years, Singapore has managed to maintain a healthy average occupancy rate of $85 \%$. At this level of occupancy, Singapore hotels operations would have been running at full capacity thus requiring a large pool of manpower to effectively support the overall operations; a resource that is increasingly scarce given the factors discussed earlier.

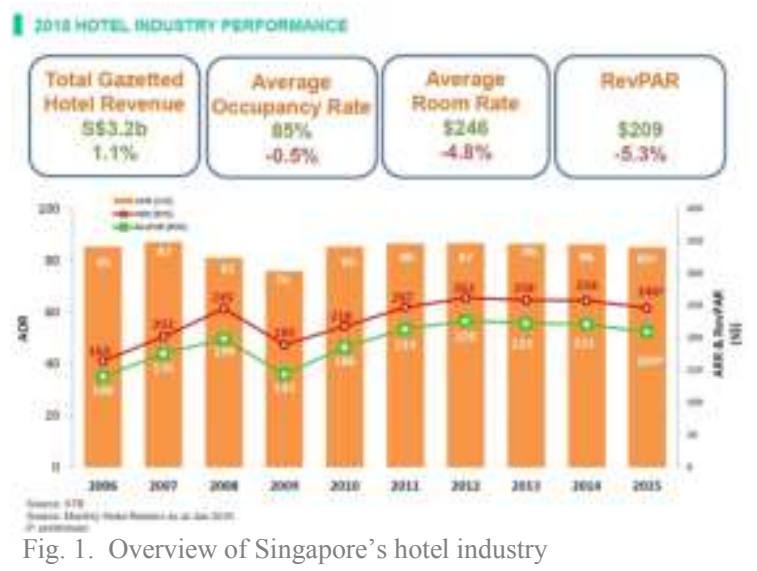

B. Hotel Pipeline at Fourth Quarter 2015

Table 1 provides information on the number of hotel rooms in the pipeline. An additional 8,514 rooms can be expected of which almost $91 \%$ are currently under construction. This will further increase the demand for manpower in the coming year.

Table 1. Hotel pipeline as of 4Q/2015 (source: Urban Redevelopment Authority)

\begin{tabular}{ll}
\hline No. of Rooms & As at 4Q/15 \\
\hline Supply in the Pipeline & 8,514 \\
Under construction & 7,712 \\
Planned development & 802 \\
\hline
\end{tabular}

C. Impact of a Tight Labour Market on the Hotel Sector

In 2010, the Singapore government first introduced measures to reduce the demand for foreign workers through imposing higher levies and adjustments to the foreign worker to Singaporean hiring ratio. Businesses reliant on human capital, such as hotels and restaurants, found it difficult to hire enough Singaporeans and therefore the corresponding number of foreign workers for their

\footnotetext{
${ }^{2}$ Refers to new development and redevelopment projects with planning approvals (i.e. Provisional Permission, Written Permission). A Written Permission (WP) is a final approval, as compared with a Provisional Permission (PP), granted under the Planning Act for a proposed development.
}

daily operation. As a result, some businesses have claimed that the shortage of manpower has affected the quality of their service (Ning, 2015). Based on the customer satisfaction measurement of the Customer Satisfaction Index of Singapore (CSISG) conducted in the last quarter of 2014, the hotels segment saw a decline of 10.4 percent to 69.4 ; its poorest performance since 2009, there may therefore be some truth to that claim.

The hotel sector is particularly affected by the tight labour market, especially the housekeeping department. Usually employing the largest proportion of staff, they are currently struggling to fill line and file positions such as, room attendants, houseman and linen attendants; jobs that are currently performed by foreign labour and not favoured by Singaporeans.

Given the shortage of labour in housekeeping departments, hotels are now exploring ways to raise their housekeeping productivity so as to be able to meet operational requirements albeit the smaller number of staff. It is therefore timely to study the applicability and impact of Lean approach on hotel operation as a way of alleviating the issues arising from the very tight labour market.

\section{About the Hotel}

The hotel under study is a midrange hotel with 229 rooms distributed over 8 floors. The guest rooms come in 4 different categories of 29 square meters or 35 square meters in size (with the exception of the suite rooms) and come fully equipped with TV and cable channels, Wi-Fi, iPod dock, telephone, minibar, ironing facilities, free toiletries, slippers and bathrobe.

Guest mix comprises both business and leisure travellers which maintains the hotel at high occupancy through-out the week, whereby weekdays guests are mainly business travellers while weekends guests are usually the group and free and independent leisure travellers. Average monthly occupancy for the past 12 months ranges from $85 \%$ to $89 \%$.

The usual check-out time is 11.00 a.m. while check-in time is at 2.00 p.m.

\section{E. Housekeeping Staff and Their Roles}

The hotel housekeeping department comprises of the following staff:

- 1 housekeeping manager who is responsible for the entire housekeeping operations.

- 3 housekeeping supervisors whose resposibilities include the following: 
- Issue the daily room cleaning assignment to room attendant (RA).

- Prepare Do Not Disturb (DND) report and the abnormal room status report.

- Issue the DND notices.

- Perform the quality inspection of rooms.

- Prepare show room for each room type.

- Coordinate with Front Desk on room clean/check out/release status.

- Check room cleaning report against room allocation plan at the end of the shift.

- 1 housekeeping coordinators whose responsibilites include the following:

- Answer guest calls.

- Stock reordering.

- Issue stock to RAs (amenities and minibar).

- Inventory management.

- 1 linen staff whose responsiblities includes the following:

- Collection of guest laundry and/or coordinate this with the RAs.

- Count staff uniform and guest laundry (in and out).

- Monthly linen stock take.

- Daily linen counting.

- Guest laundry posting for charging (in Opera system).

- There are a total of 12 room attendants (RA) whose primary responsibility are to clean room. They are also responsible for the collection of guest room supplies, stocking of pantry, handling of guest laundry and dispatching of soiled linen.

On a usual day, each RA is assigned 15 rooms of which about $45 \%$ are check-out rooms and $55 \%$ stayover or occupied rooms. The proportion varies depending on occupancy and arrival figures.

\section{METHOD}

The DMAIC (Define, Measure, Analyse, Improve and Control) approach which is commonly used in Lean Management (Juran Global, 2016) was adopted in this applied research study.

Prior to defining the study, the key objectives of the applied research study were determined, which were:

- Firstly identify the major hindrances to productivity improvements in housekeeping.

- Knowing the major hindrances redesign systems, approaches and/or processes to improve productivity.

- Lastly pilot the new and/or refined systems and processes and measure productivity gains.

A. Define
Given that housekeeping encompasses several areas, to further define the study, it was agreed with the management team that the study focuses on RAs work performance. Therefore, the applied research study was defined as a study on RA's productivity in relation to the number of rooms cleaned per day and how this can be increased through Lean thinking and approach. The study concentrated on the room attendant's daily work tasks and activities as well as the value-chain that supports them, such as, work scheduling and assignment system, daily work flow and processes, room cleaning standard operating procedures, guest amenities supply and distribution systems, guest and room linen laundry systems and processes and any other systems and processes that impacts the RA's daily work activities.

\section{B. Measure}

To gain insights into the current systems and processes efficiency and effectiveness, the following data and measurements were obtained:

- RA's work schedule, daily targets and current performance in terms of number of rooms cleaned daily to the required quality standards.

- The average time taken to clean different room types and room occupancy status (vacant dirty versus occupied room) to the desired standards.

- A detailed breakdown of the RA's daily tasks and activities from the time the RA clockin to the time he clock -out. This includes the time spent on each tasks and activities as well as the number of repetitions.

- Detailed breakdown of the room cleaning processes and the time taken for each in-room tasks and activities.

- Daily Standard Operations Procedures related to the RA duties, such as handling of guest laundry, supply (and resupply) of linen and amenities, quality assurance process, etc.

The daily activities of 5 RAs were measured over five days, that is, from Monday to Friday. Different profiles of RAs were chosen based on gender, work experience and nationality, to ensure a fair representation of the department while the readings from different days of the week were obtained to account for the possible effects of different levels of work intensity resulting from different levels of occupancy and room turnover rates.

A data collector equipped with a video recorder was assigned to each of the 5 RAs. The data collector shadowed the RAs throughout his or her entire 8-hour work shift, recording the RAs' every 
tasks and activities. The time taken to perform each tasks and activities were captured through the video recorder in-built timer system.

A total of 25 complete observations of RAs daily duties were recorded. From these 25 observations, 246 data sets of in-room cleaning processes were obtained (246 rooms were cleaned by the 5 RAs over the period of 5 days).

\section{Lean Tools Applied}

Swim lanes process flow chart was used to map the entire value chain. To do this, in-depth interviews with the Head of Department, Department Supervisors, Housekeeping Coordinators, RAs and Linen Attendants were first carried out. Process Observations of actual work flows and processes were then performed to validate the information obtained from the in-depth interviews. and motivations behind key activities so that any changes in processes could be carried out in a comprehensive and systematic manner.

\section{ANALYSIS}

\section{A. Process Flow Chart}

Fig. 2 presents the process flow chart of RAs' daily tasks and activities in a swim lane format. The housekeeping main office and linen and supplies stores are situated on the 4th level of the hotel building. Individual level refers to the room attendants' assigned floors. Each floor has a housekeeping pantry which is used for storage of housekeeping supplies, guest amenities, back-up linen, equipment and the housekeeping trolley. Level 1 is the street level where the waste bins are located. Two service lifts serve all guest room floors.

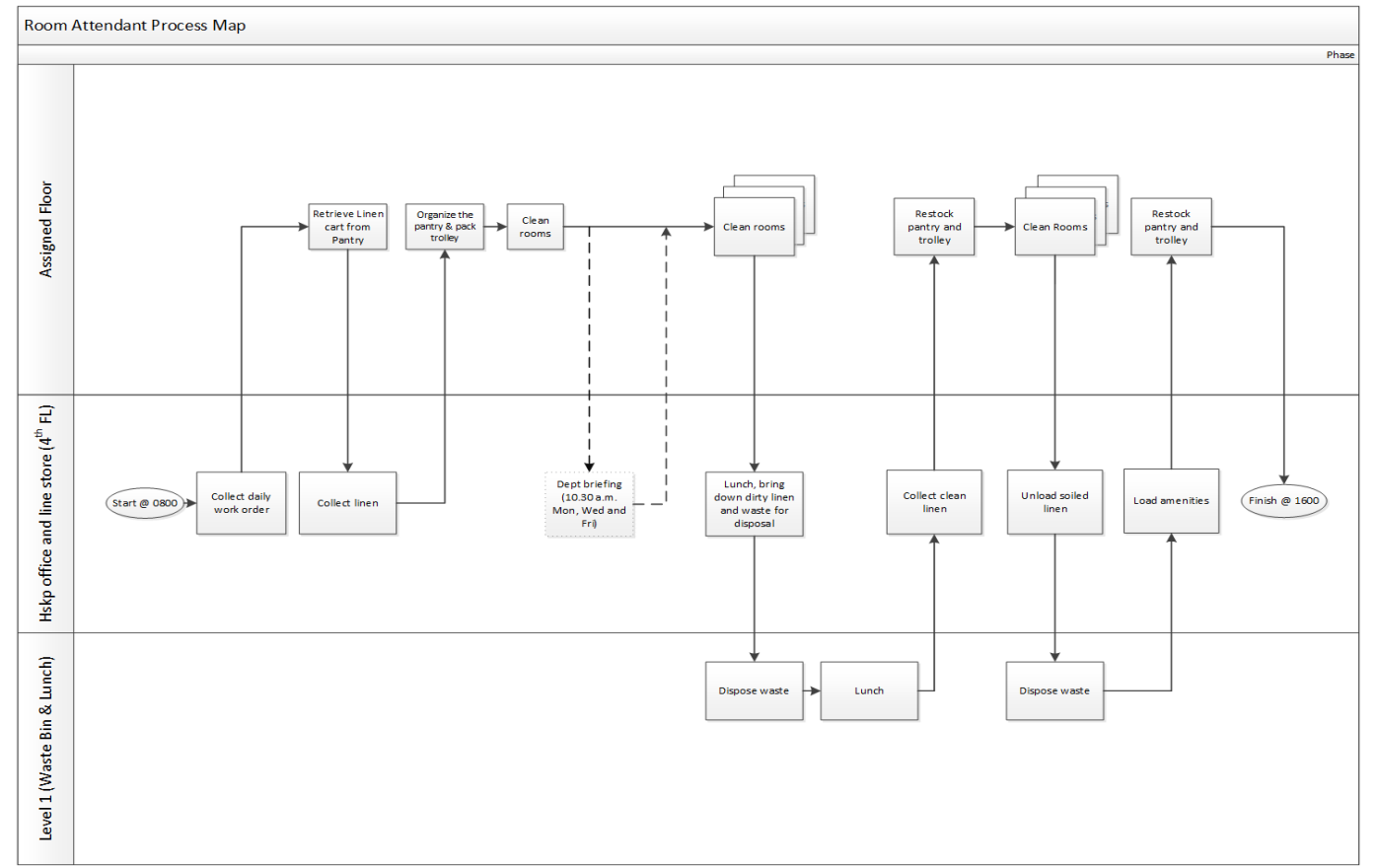

Fig. 2. Room attendant process flow chart

Quantitative measurements of the processes were obtained through a detailed time motion study of RAs' daily activities (the video recording of daily duties). The timings for all the tasks and activities were obtained from the video recording in-built timer. The average timing of each tasks and activities were determined after testing for outliers and reviewing the data set standard deviations.

These timing data were used to develop the Time Value Map of the housekeeping function, while a cause and effect diagram (Ishikawa's Diagram) was used to analyse the specific reasons
Based on the process map it is evident that RAs make 3 to 4 round trips to the housekeeping office from their designated floors. To make the round trips RAs have to first push their housekeeping trolley and linen cart to the pantry for safe keeping before taking the lift down and vice versa on the return trip.

\section{B. Time Motion Study}

The time motion study provided time based information on each activity and task performed by the RAs. A breakdown of the tasks/activities and time taken is presented in Fig. 3. 
Based on an 8-hour day (480 minutes), the average time RAs spent actually cleaning room accounts for only $56 \%$ of work shift. The remaining $44 \%$ or 211.2 minutes are used for other activities and tasks that may be necessary but not directly related to turning around a room. Since there is no similar data to benchmark against at this point in time, whether $56 \%$ is a satisfactory amount of time dedicated to cleaning room or otherwise cannot yet be determined. However it is evident from Fig. 3 that there are certainly opportunities to increase the percentage of time available to room cleaning and therefore raise room output.

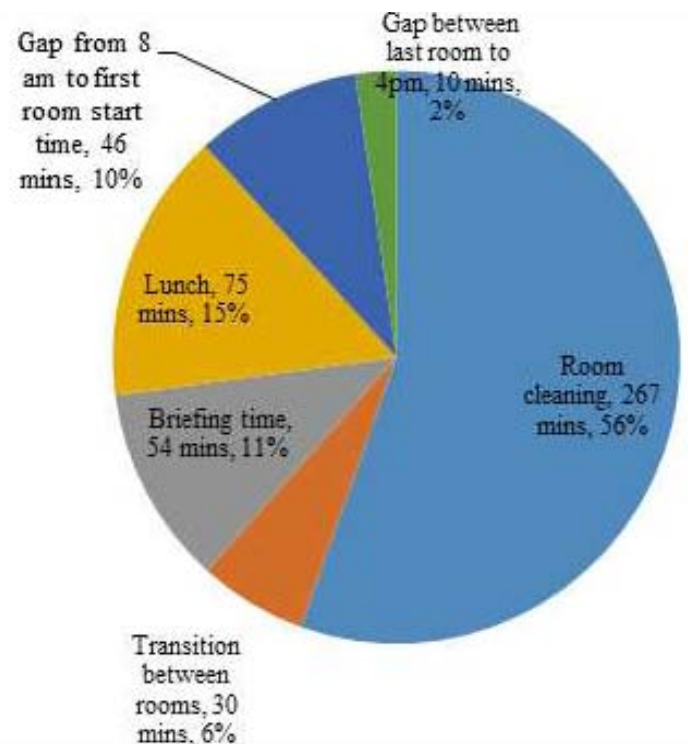

Fig. 3. Current RA daily activities/tasks

Amongst the non-room cleaning activities, the average time from when an RA clock-in for work to the time the RA starts on the first room is 46 minutes. Given that the guest check-in time is 2.00 p.m., it is imperative that the time period between 8.00 a.m. and 2.00 p.m. be optimally used to clean rooms with priorities given to check-out rooms when the hotel is expecting a large number of arrivals. Therefore, if the start-up time of 46 minutes could be shorten or even eliminated more time can be dedicated to cleaning rooms to meet the demand for rooms.

Applying Lean thinking to this operation situation, the hotel should deliver what customer needs (the room), at the time they are needed (check-in time of 2.00 p.m.), the way they need it (clean, complete and fully functioning rooms), it would mean that throughput, that is the speed at which rooms of the required quality be ready, is as important as output, that is the total number of rooms produced in a single shift.

"Lunch" is the other time consuming activity taking up 75 minutes or $15 \%$ of the RAs daily shift. Allowing 45 minutes for lunch, there is a significant 30 minutes spent before and after lunch doing activities such as, disposing of waste, collection of linen and restocking housekeeping trolley (refer to Fig. 2).

Department briefings involving all housekeeping personnel are usually conducted at 10.30 a.m. three times a week; Monday, Wednesday and Friday. The actual briefing itself averages 30 minutes, however when the time taken to store housekeeping trolley, travel to and from the briefing venue and waiting for everyone to be gathered, are added to the briefing time, the total time related to briefing is 54 minutes or $11 \%$ of the daily shift. The total time per trip (pushing the trolley and cart to the pantry and taking the lift) to the venue averages 5 minutes per trip. Therefore, if an RA makes 4 return trips per shift, the total average time travelling from floor to housekeeping office and back comes up to 40 minutes per shift, that is, $8 \%$ of daily shift hours. It was also noted that the briefing time of 10.30 a.m. is during the critical period when the operation should be focused on turning around rooms.

The transition time between rooms accounts for 30 minutes or $6 \%$ of RA daily shift. This represents the time required to travel between pantry and rooms and from rooms to rooms. It also includes time taken to search and ascertain that a room can be cleaned.

\section{Time Value Map}

The time value map of RA daily activities and tasks (Fig. 4) compares the value-add (VA) versus the non-value-add (NVA) components of the RA activities and tasks. Since the primary role of the $\mathrm{RA}$ is to clean room, VA activities are defined as those related directly to cleaning a room while the NVA are those that are not related directly to room cleaning. For example, pushing the trolley and cart from room to room, checking room occupancy and getting linen from the store are considered NVA activities while clearing waste from the room, checking for items left behind and changing bed linen are considered VA activities.

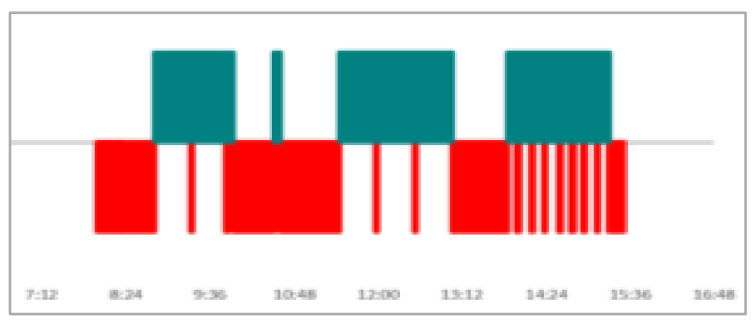

Fig. 4. Time value map of RA daily activities 


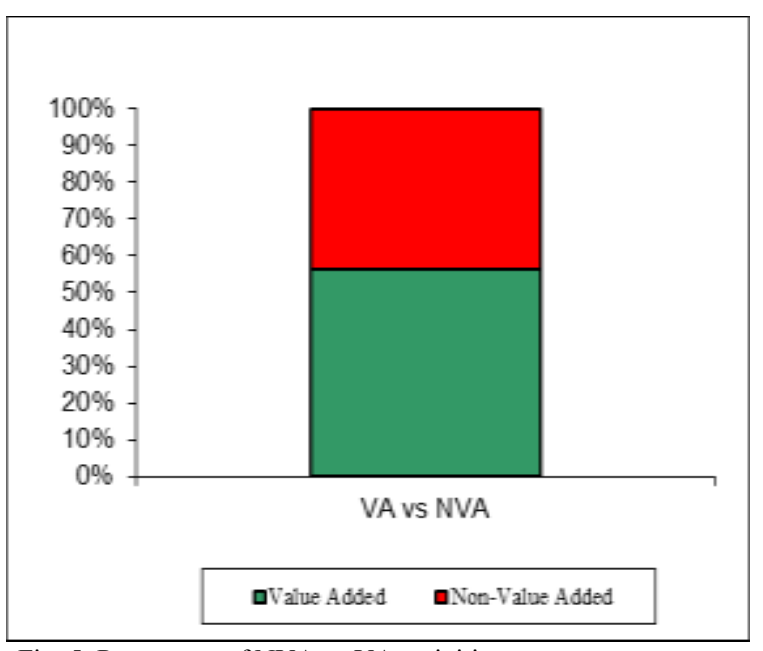

Fig. 5. Percentage of NVA vs VA activities

From the time value map, the number of NVA activities significantly out numbers the VA activities however in terms of time, VA activities constitute a higher percentage of total time than NVA activities, that is, 56\% VA activities compared to $44 \%$ NVA activities (Fig. 5).

It is important to note that some of these NVAs are the cause of unnecessary movements, referred to as waste in Lean. Three of Lean's categories of waste is evident, namely, wait, unnecessary motion and transport wastes. For example, because RAs are required to collect their own supplies (NVA) they have to commute from pantry to housekeeping office and back. As noted earlier, the total average commuting between floor and housekeeping office is 40 minutes which accounts for $19 \%$ of total NVA time while process design and supply management account for $26 \%$ of the NVA activities. For a complete list of VA and NVA activities please refer to Appendix 1.

As the key objective of this applied research study is to raise the output of the RAs in terms of rooms cleaned, it is perhaps helpful to frame the potential improvement in terms of rooms. Furthermore, since the critical operation time period is between the RA's clock-in time at 8.00 a.m. and 2.00 p.m., the official guest check-in time, the improvement effort is focused on achieving a higher room output between 8.00 a.m. to 2.00 p.m.

Table 2 provides details on the time required to clean the main category of room, namely the deluxe room which makes up $65 \%$ percent of the total rooms available. The size of the deluxe room is 29 square meter. It takes $61 \%$ more time to clean a check-out room compared to an occupied room.
Table 2. Average time to clean a deluxe room

\begin{tabular}{|l|c|c|c|c|}
\hline $\begin{array}{l}\text { Room } \\
\text { Type }\end{array}$ & $\begin{array}{c}\text { Occupied } \\
\text { Average } \\
\text { (mins) }\end{array}$ & $\begin{array}{c}\text { Number of } \\
\text { observations }\end{array}$ & $\begin{array}{c}\text { Average } \\
\text { Duration } \\
\text { (mins) }\end{array}$ & $\begin{array}{c}\text { Number of } \\
\text { Observations }\end{array}$ \\
\hline Deluxe & 18 & 132 & 29 & 48 \\
\hline
\end{tabular}

Since deluxe rooms make up the majority of rooms at the hotel, the average time to clean a checked out deluxe room, that is, 29 minutes, is used to calculate the potential number of rooms that can be cleaned as a result of the removing NVA activities.

The elimination of the 46 minutes first room of the day start time therefore theoretically translates to a potential 1.6 additional rooms per RA per shift or 19 rooms per day based on 12 room attendants per shift.

On Monday, Wednesday and Friday when the department briefings are conducted, the 54 minutes would theoretically translate to an additional 1.9 additional room per RA per shift while the 30 additional minutes during lunch would translate to 1 potential additional room per RA per shift. Therefore the potential additional rooms per RA per shift that could be realized if NVA activities were eliminated totally is 4.5 rooms which represent a potential $30 \%$ increase in the number of rooms an RA can clean from 15 rooms to 19.5 rooms.

As a department this would translate to an additional 54 rooms per day before 2.00 p.m. or $24 \%$ more cleaned rooms per day for arriving guests. This obviously is a best case scenario and reality would probably be less than the theoretical potential.

\section{Cause and Effect Diagram}

The findings indicated that the top two NVA activities are "Gap between 8 a.m. to first room start" and "Lunch". The reasons why "Lunch" takes up a significant amount of time is clear, however, the 46 minutes that it takes to start cleaning the first room of the day is not as obvious. Therefore, a cause effect diagram was created to help diagnose the reasons why it takes a significant amount of time before an RA start cleaning the first room of the day. The cause and effect diagram is illustrated in Fig. 6.

Based on the cause and effect diagram, a list of recommendations to minimize the start time delay were proposed and presented in Table 3.

\footnotetext{
3 Average cleaning duration is measured from the time the RA enters the room to clean to the time he or she exits the room.
} 


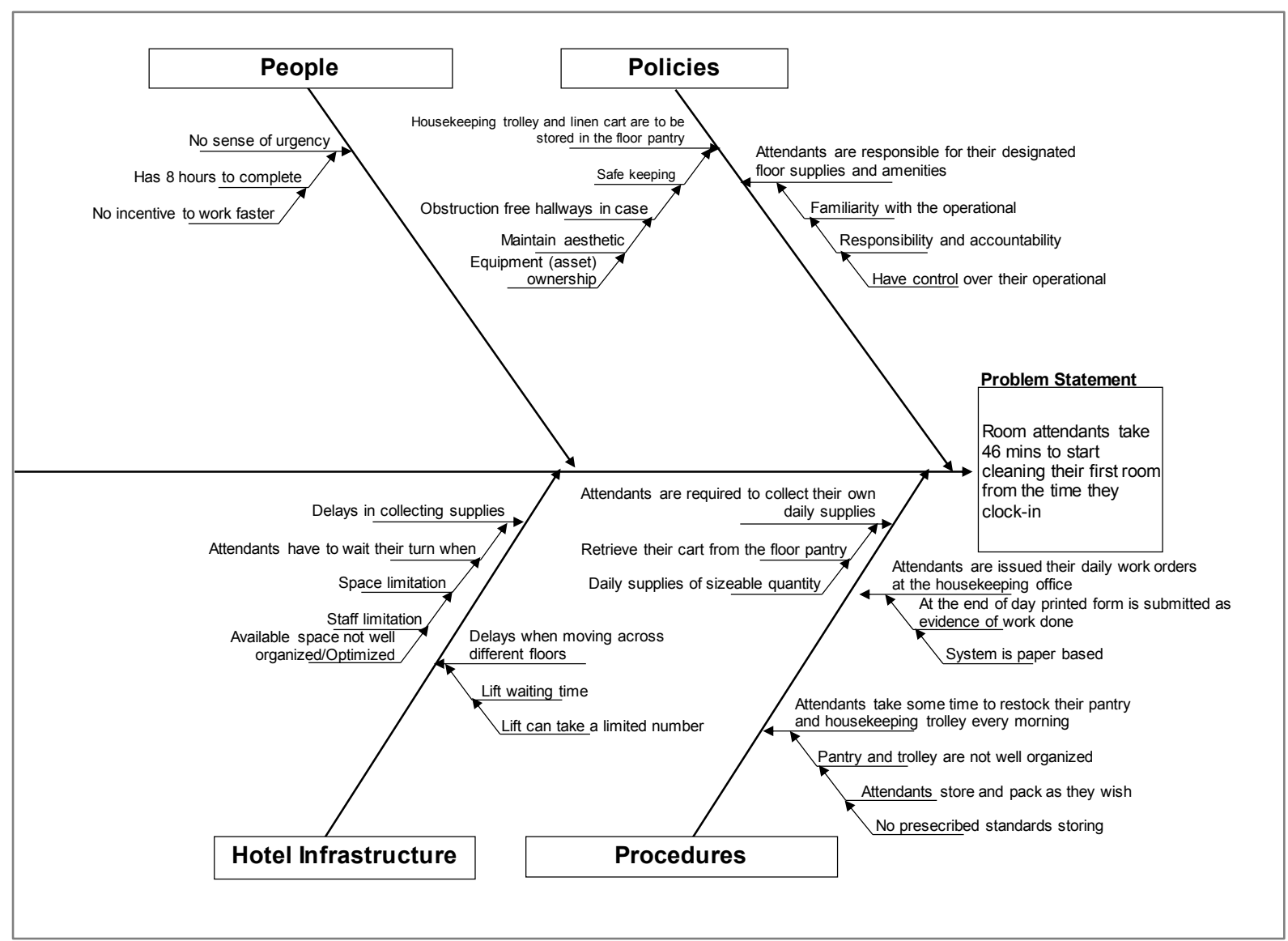

Fig. 6. Cause and effect for start of shift to first room clean 
Table 3. Table of recommendations to reduce start time

\begin{tabular}{|c|c|c|}
\hline $\begin{array}{l}\text { Functi } \\
\text { onal } \\
\text { Area }\end{array}$ & Current Situation & Recommended Change \\
\hline \multirow[t]{4}{*}{$\begin{array}{l}\text { Proce } \\
\text { dures }\end{array}$} & $\begin{array}{l}\text { Attendants are } \\
\text { required to collect } \\
\text { their own linen } \\
\text { every morning }\end{array}$ & $\begin{array}{l}\text { With the linen stocking } \\
\text { done the night before by } \\
\text { the houseman, RA will no } \\
\text { longer need to spend the } 30 \\
\text { minutes in the morning to } \\
\text { collect and organize their } \\
\text { linen supplies. }\end{array}$ \\
\hline & $\begin{array}{l}\text { Attendants take } \\
\text { some time to } \\
\text { restocked their } \\
\text { pantry and trolley } \\
\text { and based on their } \\
\text { own preference } \\
\text { and convenience. }\end{array}$ & $\begin{array}{l}\text { To eliminate waste related } \\
\text { to searching for items, } \\
\text { overstocking, and out-of- } \\
\text { stock items as well as } \\
\text { better space utilization, it is } \\
\text { recommended that the } \\
\text { housekeeping department } \\
\text { practise } 5 \mathrm{~S} \text { in organizing } \\
\text { their pantry, trolley and } \\
\text { back-of-house. }\end{array}$ \\
\hline & $\begin{array}{l}\text { Attendants receive } \\
\text { their daily work } \\
\text { orders at the } \\
\text { housekeeping } \\
\text { office because the } \\
\text { work allocation } \\
\text { system is still } \\
\text { paper based. }\end{array}$ & $\begin{array}{l}\text { It is recommended that the } \\
\text { department consider } \\
\text { investing in a } \\
\text { housekeeping management } \\
\text { system that helps automate } \\
\text { job assignment and } \\
\text { management through } \\
\text { handheld devices. } \\
\text { The latest information and } \\
\text { notices can be relayed } \\
\text { instantaneously and } \\
\text { directly to appropriate staff } \\
\text { potentially reducing waste } \\
\text { associated with } \\
\text { unnecessary movements } \\
\text { such as looking for the } \\
\text { next room to clean. }\end{array}$ \\
\hline & $\begin{array}{l}\text { Attendants are to } \\
\text { attend department } \\
\text { briefing three } \\
\text { times a week } \\
\text { (Mon, Tue, and } \\
\text { Wed) at } 10.30 \text { a.m. } \\
\text { at the } \\
\text { housekeeping } \\
\text { office. }\end{array}$ & $\begin{array}{l}\text { Department briefings to be } \\
\text { moved to the end of the } \\
\text { before clocking-out and } \\
\text { kept succinct focusing only } \\
\text { on essential topics of } \\
\text { relevant to the whole team. }\end{array}$ \\
\hline
\end{tabular}

\begin{tabular}{|l|l|l|}
\hline $\begin{array}{l}\text { Functi } \\
\text { onal } \\
\text { Area }\end{array}$ & Current Situation & Recommended Change \\
\hline People & $\begin{array}{l}\text { Current } \\
\text { performance } \\
\text { measurement and } \\
\text { work quota } \\
\text { emphasize output } \\
\text { not throughput. }\end{array}$ & $\begin{array}{l}\text { Recommends a review of } \\
\text { the work quota and } \\
\text { incentive system to place } \\
\text { emphasis to throughput. }\end{array}$ \\
\hline
\end{tabular}

\begin{tabular}{|c|c|c|}
\hline $\begin{array}{l}\text { Functi } \\
\text { onal } \\
\text { Area }\end{array}$ & Current Situation & Recommended Change \\
\hline $\begin{array}{l}\text { Poli- } \\
\text { cies }\end{array}$ & $\begin{array}{l}\text { The Housekeeping } \\
\text { trolley and linen carts } \\
\text { are stored in the floor } \\
\text { pantry to ensure the } \\
\text { security of the } \\
\text { equipment as well as } \\
\text { reduce the possibility } \\
\text { of pilferage. } \\
\text { Furthermore, to ensure } \\
\text { that the trolley and cart } \\
\text { do not pose an } \\
\text { obstacle during } \\
\text { emergency evacuation, } \\
\text { they are put away in } \\
\text { the pantry when not in } \\
\text { use. They are also kept } \\
\text { out of sight to } \\
\text { maintain the overall } \\
\text { aesthetic of the hotel } \\
\text { trolley. }\end{array}$ & $\begin{array}{l}\text { No change in this policy, } \\
\text { however it is recommended } \\
\text { that the linen and other } \\
\text { supplies be stocked up the } \\
\text { night before so that } \\
\text { attendants need not do this in } \\
\text { the morning at the start of } \\
\text { their shift. }\end{array}$ \\
\hline & $\begin{array}{l}\text { Attendants are } \\
\text { responsible for their } \\
\text { floor supplies and } \\
\text { guest amenities. }\end{array}$ & $\begin{array}{l}\text { Slight change to this policy. } \\
\text { Attendants determine the } \\
\text { standard list and quantity of } \\
\text { items required for the daily } \\
\text { operations however the } \\
\text { responsibility to maintain the } \\
\text { stock should be assigned to } \\
\text { another staff member. It is } \\
\text { recommended that a } \\
\text { houseman position be } \\
\text { introduced to stock and } \\
\text { maintain the pantries as well } \\
\text { as take over tasks that require } \\
\text { attendants to leave their } \\
\text { designate floors. For } \\
\text { example, the disposal of } \\
\text { waste, collection and delivery } \\
\text { of guest laundry and the } \\
\text { dispatch of soiled linen. } \\
\text { This will help RAs gain } 15 \\
\text { minutes which is currently } \\
\text { spent on waste disposal } \\
\text { before lunch. } \\
\text { In addition with the } \\
\text { houseman RA now need not } \\
\text { spend } 54 \text { minutes attending } \\
\text { to per guest laundry request. }\end{array}$ \\
\hline
\end{tabular}

\begin{tabular}{|l|l|l|}
\hline $\begin{array}{l}\text { Functi } \\
\text { onal } \\
\text { Area }\end{array}$ & Current Situation & Recommended Change \\
\hline $\begin{array}{l}\text { Hotel } \\
\text { Infra- } \\
\text { structure }\end{array}$ & $\begin{array}{l}\text { Given the space, } \\
\text { location and lift } \\
\text { constraint, movement } \\
\text { between floors and } \\
\text { location are usually } \\
\text { delayed. }\end{array}$ & $\begin{array}{l}\text { Although there is little that } \\
\text { can be done in the short term } \\
\text { to change infrastructure, } \\
\text { system and process can be } \\
\text { redesigned to work around } \\
\text { the infrastructure constraint. } \\
\text {-Changing the linen collection } \\
\text { time to the end-of-day or after } \\
\text { critical operation hours and } \\
\text { re-assigning it to a houseman } \\
\text { eliminates the delay in } \\
\text { cleaning the first room at the } \\
\text { start of the day caused by } \\
\text { infrastructure constraints. } \\
\text {-Better organizing (5S) the } \\
\text { pantry to cater to the full day } \\
\text { operational demand } \\
\text { eliminates the need to } \\
\text { resupply at mid-day. }\end{array}$ \\
\hline
\end{tabular}




\section{IMPROVE}

The hotel management agreed to implement the following immediately:

- Introduction of a houseman to relieve RAs of the daily NVA activities such as, linen and supplies collection from housekeeping store, stocking of pantry, waste disposal to the central bin area, collection and delivery of guest laundry and dispatching soiled linen.

- Organization of the floor pantry using $5 \mathrm{~S}$ approach to accommodate all the room supplies for a full day operations thus minimizing the need to leave the floor to for supplies.

- Rescheduling department briefing to the end of the shift and keeping the briefing succinct.

The recommendation to invest in a housekeeping management system was taken into consideration for implementation at a later date.

Fig. 7 illustrates the new streamlined process map for room attendants. From having to make 4 round trips to the housekeeping office, RAs now only need to make 1 round trip for lunch. This significantly reduce waste related to "unnecessary movement" and "waiting" for the RAs.
Table 4 summarizes the estimate amount of RA time currently consumed by NVA activities the new processes hope to free.

\begin{tabular}{|c|c|}
\hline Changes to RA activities & $\begin{array}{l}\text { Time } \\
\text { saving } \\
\text { (minutes) }\end{array}$ \\
\hline $\begin{array}{l}\text { 1. Restocking of supplies in the } \\
\text { morning }\end{array}$ & 40 \\
\hline $\begin{array}{l}\text { 2. Removal of waste disposal } \\
\text { task }\end{array}$ & 10 \\
\hline $\begin{array}{l}\text { 3. Removal of the need to } \\
\text { restock at mid-day }\end{array}$ & 15 \\
\hline Total & 65 \\
\hline $\begin{array}{l}\text { 1. Retiming of department } \\
\text { briefing (only on Mon, Wed } \\
\text { and Fri.) }\end{array}$ & 34 \\
\hline
\end{tabular}

Through-out the week, the target time saving is 65 minutes per shift while on the days when there are briefing, the target time savings is 99 minutes.

The implementation of the new processes was spearheaded by the hotel's housekeeping manager with full support from the hotel General Manager. As a control measure, the hotel tracks room

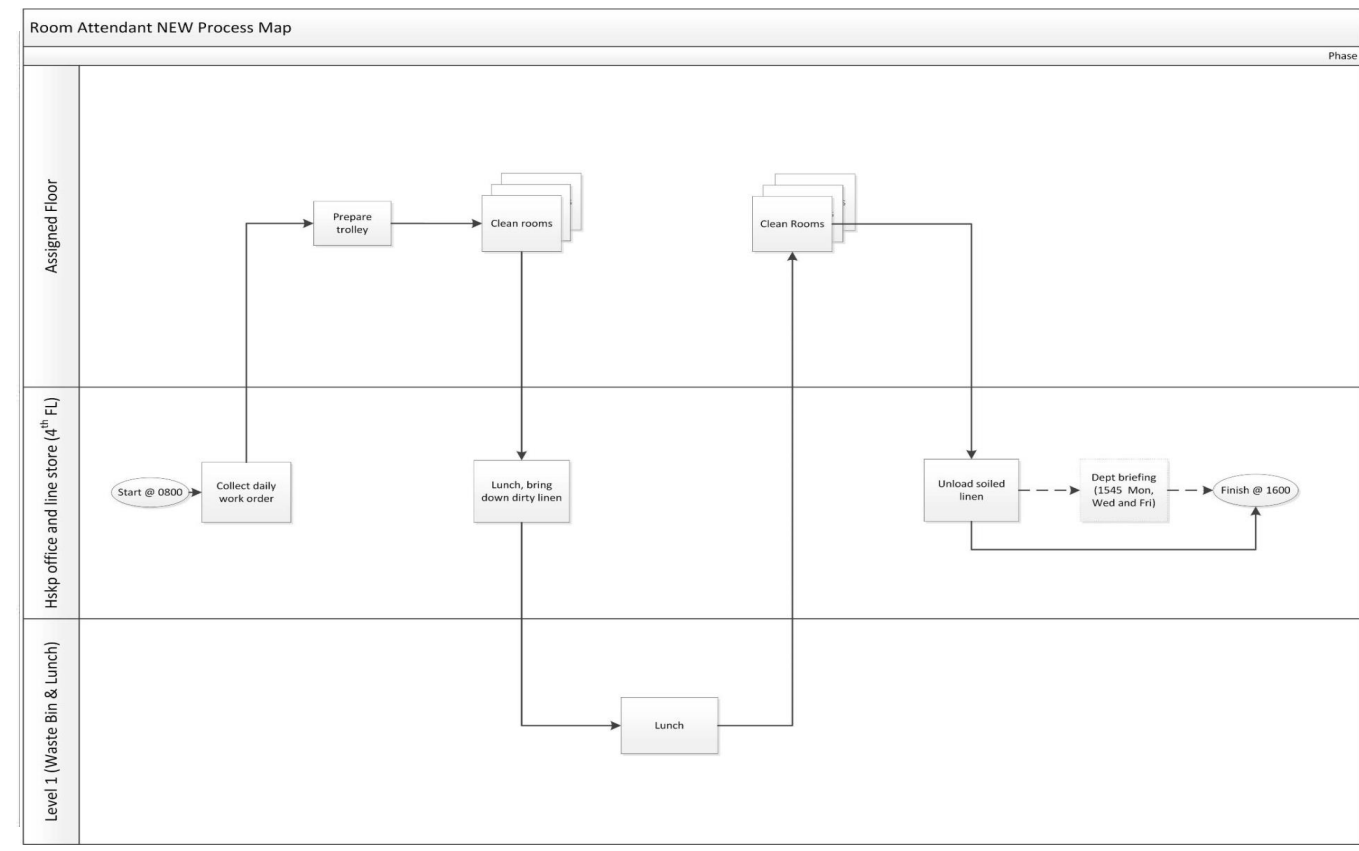

Fig. 7. RA streamlined process map

attendants' work output based on the total number of rooms cleaned daily as well as the number of rooms cleaned by 2.00 p.m.

\section{CONTROL}

Post implementation measurements were taken 6 weeks after the new processes were implemented. The housekeeping manager reported that there were initial resistance from room attendants when their daily room cleaning quota was increased from 15 rooms to 20 rooms. However after some negotiation, the RAs and management team has 
agreed to a revised quota of 18 rooms per day with added incentive if $80 \%$ (14 rooms) of the daily room quota is completed by 2.00 p.m. In addition, all additional rooms beyond the daily quota of 18 will be paid at over time rate even if the rooms are cleaned within the RA's regular shift hours. No additional cost was incurred because the hotel was already paying RAs overtime rate for additional rooms cleaned after the regular shift hours.

The new quota of 18 rooms per day represents a $20 \%$ increase in daily room output.

A post implementation time and motion study was conducted after the new processes were implemented and the readings are presented in Fig. 8.

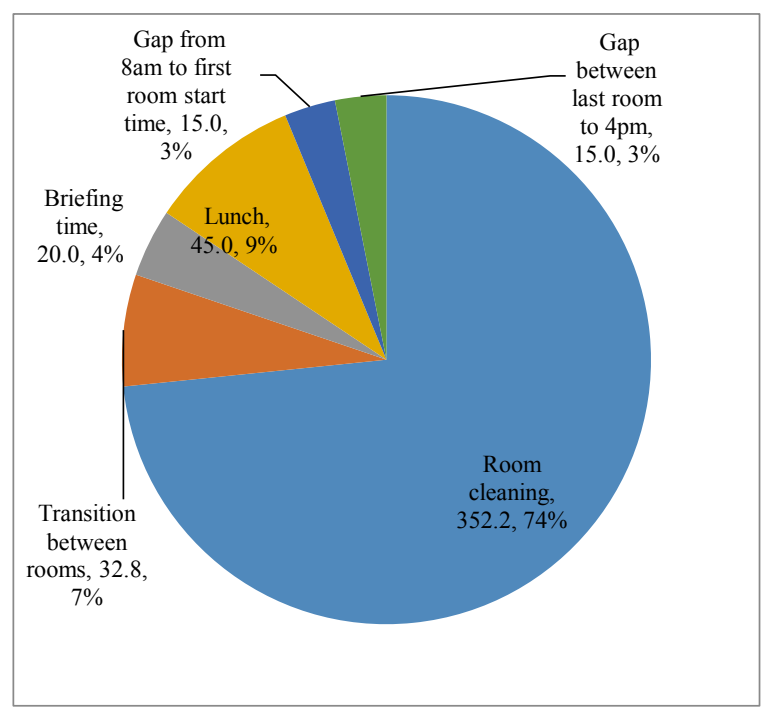

Fig. 8. Post implementation RA daily activities/tasks

The readings indicated that the time dedicated to cleaning (VA activities) has increased by $18 \%$ from $56 \%$ to $74 \%$. This means an additional 85 minutes to the RA's daily cleaning time allowing RA to complete the additional daily quota of 3 rooms.

The total number of additional rooms per day achieved totalled 36 rooms based on the 12 room attendants currently employed. This is equivalent to 2 additional RAs based on a daily quota of 18 rooms. Since 1 additional headcount was introduced that is, the houseman, the net gain amounts to the work done by one full time RA. Note that the gap between the last room cleaned to 4 p.m. has increased because the department briefings are now conducted at the end of the day.

\section{CONCLUSION}

This applied research study provides evidence that Lean can be applied to hotel operations and can have a significant impact on work outcome. By eliminating wastes and streamlining processes using Lean approach, the hotel under study was able to increase the time available for cleaning rooms by an additional 85 minutes thus allowing
RAs to achieve $20 \%$ higher room output. Although part of the productivity gain was offset by the introduction of one additional headcount the net gain achieved exceeded the additional headcount increase.

To drive output and efficiency event further, hotels should also explore the possibility of automation, as did the manufacturing industry, through the use of Information technology, RFID and robotics.

\section{REFERENCES}

Abdi, f., Shavarini, S. K., \& Hoseini, S. M. (2006). Glean lean how to use lean approach in service industries. Journal of Services Research, 191-206. Alsmadi, m., Almani, A., \& Jerisat, R. (2012). A comparative analysis of Lean practices and performance in the UK manufacturing and service sector firms. Total Quality Management Vol 23, No. 4, 381-396.

Bhuiyan, N., \& Baghel, A. (2005). An overview of continuous improvement: from the past to the present. Management Decision 43(5), 761-771. Chartered Institute of Management Accountants. (2 September, 2013). CIMA. Retrieved 4 April, 2016, from Global CIMA survey reveals Gen Y is "generation aspiration":

http://www.cimaglobal.com/About-us/Pressoffice/Press-releases/2013/Global-CIMA-surveyreveals-Gen-Y-is-Generation-Aspiration/ Costa, S. E., Lima, E. P., \& Garbuio, P. A. (2014). Lean, Six Sigma and Lean Six Sigma: an anlaysis based on operations strategy. International Journal of Production Research Vol. 52 No. 3, 804-824.

Department of Statistics. (September, 2015). Department of Statistics. Retrieved 4 April, 2016, from Statistics Singapore - Populatoin Trends 2015: http://www.singstat.gov.sg/docs/defaultsource/default-document-

library/publications/publications_and_papers/popul ation_and_population_structure/population2015.pd $\mathrm{f}$

Department of Statistics Singapore. (14 March, 2016). General household survey 2015 . Retrieved 31 March, 2016, from Department of Statistics Singapore Publications:

http://www.singstat.gov.sg/publications/publication s-and-papers/GHS/ghs2015content

Economic Strategies Commitee. (30 January, 2010). ECDL Foundation. Retrieved 31 March, 2016, from ECDL Media:

http://www.ecdl.org/media/Singapore\%20Economi c\%20Committe 2010.pdf

Economy Strategies Committee. (3 November, 2011). Ministry of Trade and Industry Singapore. Retrieved 31 March, 2016, from Economic Strategies Committee: 
https://www.mti.gov.sg/AboutMTI/Pages/Economi c-Strategies-Committee.aspx

Hayes, R., \& Pisano, G. (1996). Manufacturing Strategy: At an intersaction of two paradigms shifts. Production and Operations Management 5 (1), 25-41.

Ho, B. (2012). The Singapore Conversation: Visions of a flourishing society. Social Alternatives, Vol 31, Issue 4, p52 - 53. Juran Global. (2016). DMAIC: The Lean Six Sigma Steps. Retrieved 12 April, 2016, from Juran Global: http://www.juran.com/resources/juranuniversity/dmaic/

Ministry of Manpower. (15 February, 2012). MOM. Retrieved 4 April, 2016, from Written Answer by Tharman Shanmugaratnam, Deputy Prime Minister, Minister for Finance and Minister for Manpower, to Parliamentary Question on foreign labour in local workforce:

http://www.mom.gov.sg/newsroom/parliamentquestions-and-replies/2012/written-answer-bytharman-shanmugaratnam-deputy-prime-ministerminister-for-finance-and-minister-for-manpowerto-parliamentary-question-on-foreign-labour-inlocal-workforce

National Population and Talent Division PMO Singapore. (2012). Issues Paper 2012 - Our demographic challenges adn what these means to us. Retrieved 4 April, 2016, from Our population our future: http://population.sg/keychallenges/\#shrinking

Ning, T. S. (6 January, 2015). Keeping customers satisfied as the labour crunch bites. The Business

Times, p. 11.

Singapore Ministry of Manpower. (19 January, 2016). Ministry of Manpower's addendum to the president address 2016. Retrieved 31 March, 2016, from Ministry of Manpower:

http://www.mom.gov.sg/newsroom/pressreleases/2016/0119-ministry-of-manpowersaddendum-to-the-presidents-address-2016
Singapore Polytechnic. (14 January, 2014).

Singapore Polytechnic Survey: Singapore youth aspire to financial stability, strong family relationships and work-life balance. Retrieved 4 April, 2016, from Singapore Polytechnic Media Room: http://www.sp.edu.sg/wps/portal/vpspws/!ut/p/a0/04 Sj9CPykssy0xPLMnMz0vMAfG jzOJDPUxdjdxMTQzcQ0MNDDy9QsyNXQOcDf wtjfQLsh0VAR1ImN0!/?PC_Z7_UH5E2F540GU U00IJT73EPC0OP0027774_WCM_CONTEXT=/ wps/wcm/connect/lib-spws/site-

spwebsite/media/press + releases/singapore + p Soon, D., \& Thia, J. P. (2012). Foreign Workers and within inudsry dynamics. Singapore Economic Review, Vol 57, No. 4, 1250026-1 - 1250026-15. Voss, C. (2005). Alternative Paradigms for Manufacturing Strategy. International Journal of Operations \& Production Management 25 (12), 1211-1222.

Ward, P., \& Duray, R. (2000). Manfucaturing strategy in context: Environment, competitive strategy and manufacturing strategy. Journal of Operations Management 18(2), 123 - 138. Womack, J. P., \& Jones, D. T. (1996). Lean Thinking. New York: Simon \& Schuster. Womack, J. P., \& Jones, D. T. (2003). Lean Thinking: Banish waste and create wealth in your corporation. New York: Free Press.

Wood, N. (2004). Lean Thinking: what it is and what it si not? Management Services, 8-11. Wormack, J. P., Jones, D. T., \& Roos, D. (1990). The machine that changed the world: The story of lean production - Toyota's secret weapon in the global car wars that is now revolutinizing world industry. Free Press.

Yusuf, Y., Gunasekaran, A., \& Dan, G. (2007). Implementation of TQM in China and organization Performance: An Empirical Investigation. Total Quality Management, 509-530. 
XI. APPENDIX 1

\begin{tabular}{|c|c|c|c|}
\hline Activity & $\begin{array}{l}\text { Touc } \\
\text { h } \\
\text { Time }\end{array}$ & $\begin{array}{l}\text { Queue } \\
\text { (Wait) } \\
\text { Time }^{4}\end{array}$ & $\begin{array}{l}\mathrm{VA}= \\
1 \\
\text { NVA } \\
=-1 \\
\end{array}$ \\
\hline Clock-in & $0: 01$ & 0:01 & -1 \\
\hline $\begin{array}{l}\text { Retrieve linen } \\
\text { trolley from floor } \\
\text { pantry }\end{array}$ & $0: 04$ & 0:01 & -1 \\
\hline Go to hkp office & $0: 03$ & $0: 01$ & -1 \\
\hline $\begin{array}{l}\text { Get room check- } \\
\text { list }\end{array}$ & 0.01 & :02 & -1 \\
\hline $\begin{array}{l}\text { Draw linen and } \\
\text { load into linen } \\
\text { trolley }\end{array}$ & $0: 10$ & 0:03 & -1 \\
\hline $\begin{array}{l}\text { Proceed to } \\
\text { designate floor } \\
\text { pantry }\end{array}$ & 0:08 & $0: 00$ & -1 \\
\hline $\begin{array}{l}\text { Prepare hkp } \\
\text { trolley }\end{array}$ & $0: 10$ & $0: 00$ & -1 \\
\hline Proceed to room 1 & $0: 03$ & $0: 00$ & -1 \\
\hline Clean room 1 & $0: 35$ & $0: 00$ & 1 \\
\hline Proceed to room 2 & $0: 01$ & $0: 00$ & -1 \\
\hline Clean room 2 & $0: 29$ & $0: 00$ & 1 \\
\hline Proceed to room 3 & & $0: 00$ & -1 \\
\hline Clean room 3 & 0.04 & $0: 01$ & 1 \\
\hline $\begin{array}{l}\text { Send guest } \\
\text { laundry to linen } \\
\text { dept }\end{array}$ & $0: 30$ & 0:01 & -1 \\
\hline Return to room & $0: 05$ & $0: 01$ & -1 \\
\hline Clean room & & $0: 00$ & 1 \\
\hline $\begin{array}{l}\text { Push tr } \\
\text { pantry }\end{array}$ & & $: 01$ & -1 \\
\hline $\begin{array}{l}\text { Proceed to hkp } \\
\text { office for briefing } \\
\text { (Mon, Wed and } \\
\text { Thu) }\end{array}$ & & 00 & -1 \\
\hline $\begin{array}{l}\text { Pick up additional } \\
\text { room } \\
\text { supplies/amenities }\end{array}$ & $0: 10$ & 0:01 & -1 \\
\hline $\begin{array}{l}\text { Return to floor } \\
\text { pantry }\end{array}$ & $0: 03$ & 0:01 & -1 \\
\hline Proceed to room 4 & $0: 02$ & $0: 00$ & -1 \\
\hline Clean room 4 & $0: 35$ & $0: 00$ & 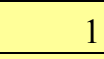 \\
\hline Proceed to room 6 & $0: 02$ & $0: 00$ & -1 \\
\hline Clean room 6 & $0: 36$ & $0: 00$ & 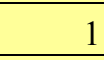 \\
\hline Proceed to room 7 & $0: 02$ & $0: 00$ & -1 \\
\hline Clean room 7 & $0: 36$ & $0: 00$ & \\
\hline
\end{tabular}

${ }^{4}$ Additional accumulated wait time of 3 minutes for room confirmation is not reflected in the table due to the short nature of each occasion

\begin{tabular}{|l|r|r|r|}
$\begin{array}{l}\text { Return hkp trolley } \\
\text { to pantry }\end{array}$ & $0: 02$ & $0: 00$ & -1 \\
\hline $\begin{array}{l}\text { Push linen cart to } \\
\text { hkp office for off } \\
\text { loading }\end{array}$ & $0: 05$ & $0: 00$ & -1 \\
\hline $\begin{array}{l}\text { Proceed to } \\
\text { dumpster to } \\
\text { dispose waste }\end{array}$ & $0: 10$ & $0: 00$ & -1 \\
\hline Load linen cart & $0: 10$ & $0: 00$ & -1 \\
\hline $\begin{array}{l}\text { Push linen cart to } \\
\text { floor pantry }\end{array}$ & $0: 08$ & $0: 00$ & -1 \\
\hline Arrange trolley & $0: 10$ & $0: 00$ & -1 \\
\hline Proceed to room 8 & $0: 02$ & $0: 00$ & -1 \\
\hline Clean room 8 & $0: 09$ & $0: 00$ & 1 \\
\hline Proceed to room 9 & $0: 02$ & $0: 00$ & -1 \\
\hline Clean room 9 & $0: 10$ & $0: 00$ & 1 \\
\hline $\begin{array}{l}\text { Proceed to room } \\
10\end{array}$ & $0: 02$ & $0: 00$ & -1 \\
\hline Clean room 10 & $0: 09$ & $0: 00$ & 1 \\
\hline $\begin{array}{l}\text { Proceed to room } \\
11\end{array}$ & $0: 02$ & $0: 00$ & -1 \\
\hline Clean room 11 & $0: 11$ & $0: 00$ & 1 \\
\hline $\begin{array}{l}\text { Proceed to room } \\
12\end{array}$ & $0: 02$ & $0: 00$ & -1 \\
\hline Clean room 12 & $0: 09$ & $0: 00$ & 1 \\
\hline $\begin{array}{l}\text { Proceed to room } \\
13\end{array}$ & $0: 02$ & $0: 00$ & -1 \\
\hline Clean room 13 & $0: 08$ & $0: 00$ & 1 \\
\hline $\begin{array}{l}\text { Proceed to room } \\
14\end{array}$ & $0: 02$ & $0: 00$ & -1 \\
\hline Clean room 14 & $0: 09$ & $0: 00$ & 1 \\
\hline $\begin{array}{l}\text { Proceed to room } \\
15\end{array}$ & $0: 02$ & $0: 00$ & -1 \\
\hline Clean room 15 & $0: 09$ & $0: 00$ & 1 \\
\hline $\begin{array}{l}\text { Return hkp trolley } \\
\text { to pantry }\end{array}$ & $0: 03$ & $0: 00$ & -1 \\
\hline Maintain pantry & $0: 05$ & $0: 01$ & -1 \\
\hline $\begin{array}{l}\text { Proceed to hkp } \\
\text { office for clock- } \\
\text { out }\end{array}$ & & & \\
\hline Clock-out & & -1 \\
\hline & & \\
\hline
\end{tabular}

